\section{Emergence of Spring- and Summer- planted Onions following Osmotic Priming}

\author{
Glen A. Murray and Jerry B. Swensen ${ }^{2}$ \\ Department of Plant, Soil, and Entomological Sciences, University of \\ Idaho, Moscow, ID 83843-4196
}

\author{
Gary Beaver ${ }^{3}$ \\ Department of Plant, Soil, and Entomological Sciences, University of \\ Idaho, Parma, ID 83660-9637
}

Additional index words. polyethylene glycol, Allium cepa

\begin{abstract}
The effect of osmotic priming on onion (Allium cepa L.) seedling emergence was evaluated in the field and in a controlled environment at $15 \mathrm{C}$. Seeds of onion cultivars Bronze Wonder, Challenger, Big Mac, and White Keeper were primed in a solution of $300 \mathrm{~g}$ polyethylene glycol 8000/liter for 7 days at 10C 1 to 2 weeks before being planted in Spring 1986 and Summer 1987. Time to 50\% of maximum emergence $\left(T_{50}\right)$ for seedlings from primed seeds averaged $10 \%$ to $12 \%$ less than for unprimed seeds in both seasons and in laboratory experiments. Maximum emergence was improved $7 \%$ by priming in one spring field experiment but not in the summer field experiments or in the laboratory. Differences in $T_{50}$ among cultivars in the 1986 experiments were small and significant only in one laboratory experiment. In 1987, cultivar differences in $\mathbf{T}_{50}$ were significant but not consistent in all experiments. Cultivar $\mathbf{T}_{50}$ means from laboratory experiments were significantly $(P=0.05)$ correlated with those for field emergence in three of four experiments, but coefficients were low $(r=0.37$ to $r=0.45)$. Values for maximum emergence in the laboratory were not correlated with maximum emergence in the field. Laboratory emergence tests at $15 \mathrm{C}$ were a poor predictor of field emergence. Seed priming may benefit establishment of spring-seeded onions emerging at soil temperatures $\leq 15 \mathrm{C}$ more than summer-seeded onions emerging in soils $>\mathbf{2 4 C}$.
\end{abstract}

Onions are planted from late February to early April for dry bulb production in southern Idaho when soil temperatures at a $10-\mathrm{cm}$ depth average $15 \mathrm{C}$ or lower and moisture levels are variable. Onions grown for seed production are planted in July when temperatures at a $10-\mathrm{cm}$ depth average $24 \mathrm{C}$ or higher and require frequent irrigation for successful germination and emergence.

During spring and summer emergence, onion seedlings are subjected to stresses that limit emergence. Drying of soils between irrigations can create soil crusts that can hinder emergence (Hegarty, 1976). Low soil temperature results in delayed emergence and increased exposure to biotic and abiotic stresses. Osmotic seed priming may reduce or alleviate these stresses.

Laboratory studies have shown that os-

Received for publication 19 Sept. 1991. Accepted for publication 23 Jan. 1992. Idaho Agricultural Experiment Station Journal Article 91760. This research was largely supported by grants from the Idaho-Eastern Oregon Onion Committee. The assistance of Mary DeVoy in conducting the field experiments is gratefully acknowledged. The cost of publishing this paper was defrayed in part by the payment of page charges. Under postal regulations, this paper therefore must be hereby marked advertisement solely to indicate this fact. 'Professor.

${ }^{2}$ Research Associate.

${ }^{3}$ Former Associate Professor. Current address: Siarco, 27080 Pearl Rd., Parma, ID 83660. motically primed onion seeds germinate more quickly and often more uniformly than unprimed seeds (Brocklehurst and Dearman, 1983a; Furutani et al., 1986). Thus, seed priming has potential to improve establishment of either spring- or summer-planted onions by reducing the window of susceptibility to crusting and damping off and by improving seedling vigor.

The relationship between plant density and marketable yield of onion bulbs has been determined for some production areas (Shock et al., 1989; Young, 1989). Early emergence of spring-sown onions resulted in larger seedlings, earlier maturity, increased bulb diameter, and increased total yield compared to seedlings that emerged 12 days later (Lipe and Skinner, 1979). Thus, seed priming may enhance bulb yield potential and market class of onion if priming resulted in earlier seedling establishment or more optimal plant populations.

The purpose of this study was to determine whether primed onion seed emerged faster and resulted in increased stands compared to unprimed seed in spring and summer field plantings. Parallel sets of emergence experiments were conducted in the laboratory to determine whether emergence under controlled conditions at $15 \mathrm{C}$ could accurately predict field emergence.

Seed lots for both spring and summer plantings of 'Bronze Wonder', 'Challenger', 'Big Mac', and 'White Keeper' onion were obtained from Crookham Seed Co. (Caldwell, Idaho) in Mar. 1986 and 1987. Laboratory germination tests showed that seed lot viability was high: $90 \%$ to $95 \%$ and $94 \%$ to $96 \%$ in 1986 and 1987, respectively. Two to 3 weeks before planting, seeds of each cultivar were primed at $10 \mathrm{C}$ in polyethylene glycol 8000 (PEG) at $300 \mathrm{~g}$.liter ${ }^{-1}$ for 7 days. We used sealed petri dishes with 50 seeds/ dish placed on four 90-mm Whatman \#1 filter papers saturated with $8 \mathrm{ml}$ of PEG solution. After treatment, seeds were rinsed in distilled water, bulked by cultivar, spread on toweling, and dried to original moisture levels $\left(\approx 40 \mathrm{mg} \cdot \mathrm{g}^{-1}\right)$.

Seedling emergence was measured under field conditions with sprinkler irrigation in a greenleaf silt loam (fine-silty, mixed, mesic, Xerollic Haplargids) at the Southwest Idaho Research and Extension Center, Parma, and in the laboratory under controlled conditions. In the field, seeds were planted 1.9 $\mathrm{cm}$ deep with a cone seeder in 10.6-m rows $53 \mathrm{~cm}$ apart with 120 seeds/row. Planting dates were 18 Apr. and 15 July 1986 and 14 Apr. and 10 July 1987. Each cultivar and seed treatment combination was replicated four times in a split-plot design with cultivars as main plots and priming treatments as subplots. Plant counts were made every 2 to 4 days from initial emergence until either no further emergence occurred or some plant loss was evident. Air and soil temperatures at $10 \mathrm{~cm}$ were recorded by a weather station at the research and extension center.

In the laboratory tests, 10 seeds of each cultivar, either primed or untreated, were planted $1 \mathrm{~cm}$ deep in $375-\mathrm{ml}$ pots with commercial potting mix (Sunshine Potting Mix no. 1, Complete; Fisons Horticulture, Vancouver, B.C.) that was watered to field capacity. The pots were put in a growth chamber at $15 \mathrm{C}$ as a randomized complete-block design with four replications. Emergence was observed daily for 2 weeks after initial emergence.

Seedling emergence was evaluated by 1) the maximum percentage of seedlings emerged and 2) the time needed to reach $50 \%\left(\mathrm{~T}_{50}\right)$ of this maximum value. The highest emergence was considered maximum, while $\mathrm{T}_{50}$ was calculated by linear interpolation between the two emergence observations that bracketed the $\mathrm{T}_{50}$ value. This calculation was performed individually for each experimental unit. Within each year and planting season, variance of $\mathrm{T}_{50}$ and maximum emergence in the field and controlled environments were analyzed separately. Means were separated using a protected LSD at $P=0.05$. To compare field emergence with emergence in the laboratory tests at $15 \mathrm{C}$, simple correlation coefficients were calculated using the $\mathrm{T}_{50}$ and maximum emergence values for each cultivar and priming treatment combination in each replicate.

Seedlings from primed onion seed emerged $7 \%$ to $18 \%$ sooner than seedlings from unprimed seed in all field and laboratory experiments (Table 1). The difference in time to $T_{50}$ was greatest in the spring field experiments where seedlings from primed seed 
Table 1. Time to $50 \%$ of maximum emergence $\left(\mathrm{T}_{50}\right)$ of onion seedlings from PEG-primed and unprimed seed planted either in spring (April) or summer (July) in the field in each of 2 years or in the laboratory at $15 \mathrm{C}$.

\begin{tabular}{|c|c|c|c|c|c|}
\hline \multirow[b]{3}{*}{ Year } & \multirow[b]{3}{*}{ Treatment } & \multicolumn{4}{|c|}{$\mathrm{T}_{30}$ (days) $^{\mathbf{z}}$} \\
\hline & & \multicolumn{2}{|c|}{ Spring } & \multicolumn{2}{|c|}{ Summer } \\
\hline & & Field & Lab. & Field & Lab. \\
\hline \multirow[t]{2}{*}{1986} & $\begin{array}{l}\text { Control } \\
\text { Primed }\end{array}$ & $\begin{array}{l}22.7 \\
20.2\end{array}$ & $\begin{array}{r}10.2 \\
9.2\end{array}$ & $\begin{array}{l}13.6 \\
12.7\end{array}$ & $\begin{array}{r}10.0 \\
8.2\end{array}$ \\
\hline & $\begin{array}{l}L^{L S D_{0.05}} \\
\text { Difference }(\%)^{y}\end{array}$ & $\begin{array}{l}0.6 \\
11\end{array}$ & $\begin{array}{l}0.5 \\
10\end{array}$ & $\begin{array}{l}0.4 \\
7\end{array}$ & $\begin{array}{l}0.5 \\
18\end{array}$ \\
\hline \multirow[t]{4}{*}{1987} & Control & 14.5 & 14.9 & 12.0 & 12.9 \\
\hline & Primed & 12.3 & 13.9 & 10.5 & 12.0 \\
\hline & $\operatorname{LSD}_{0.05}$ & 0.6 & 0.8 & 0.7 & 0.1 \\
\hline & Difference & 15 & 7 & 13 & 7 \\
\hline
\end{tabular}

${ }^{2}$ Values are means of four onion cultivars and four replications.

yPercent difference relative to the control.

Table 2. Time to 50\% of maximum emergence $\left(T_{50}\right)$ of four cultivars of onion seeds planted in either the field or in the laboratory at $15 \mathrm{C}$ during spring (April) or summer (July) in each of 2 years. Simple correlation coefficients relating field emergence to emergence in the laboratory at $15 \mathrm{C}$ are presented for each planting season in each year.

\begin{tabular}{|c|c|c|c|c|c|}
\hline \multirow[b]{3}{*}{ Year } & \multirow[b]{3}{*}{ Cultivar } & \multicolumn{4}{|c|}{$\mathrm{T}_{30}$ (days) $^{\mathrm{z}}$} \\
\hline & & \multicolumn{2}{|c|}{ Spring } & \multicolumn{2}{|c|}{ Summer } \\
\hline & & Field & Lab. & Field & Lab. \\
\hline \multirow{6}{*}{1986} & Bronze Wonder & 22.1 & 9.1 & 13.4 & 8.9 \\
\hline & Challenger & 21.3 & 10.2 & 12.8 & 9.4 \\
\hline & Big Mac & 21.6 & 9.7 & 13.1 & 8.9 \\
\hline & White Keeper & 20.8 & 9.6 & 13.3 & 9.2 \\
\hline & $\mathrm{LSD}_{0.05}$ & NS & 0.7 & NS & NS \\
\hline & & \multicolumn{2}{|c|}{$r=0.45^{* *}$} & \multicolumn{2}{|c|}{$r=0.38^{*}$} \\
\hline \multirow[t]{6}{*}{1987} & Bronze Wonder & 14.5 & 14.8 & 11.6 & 13.1 \\
\hline & Challenger & 12.4 & 12.4 & 10.2 & 12.8 \\
\hline & Big Mac & 13.4 & 15.2 & 11.8 & 12.1 \\
\hline & White Keeper & 13.4 & 15.3 & 11.3 & 11.7 \\
\hline & $\mathrm{LSD}_{0.05}$ & 0.91 & 1.1 & 0.93 & 0.6 \\
\hline & & \multicolumn{2}{|c|}{$r=0.37^{*}$} & \multicolumn{2}{|c|}{$r=0.09$} \\
\hline
\end{tabular}

${ }^{2}$ Values are means of primed and unprimed seeds of each cultivar, replicated four times.

*,* *Significant correlation coefficient at $P=0.05$ or 0.01 , respectively.

emerged an average of 2 days (13\%) sooner than those from unprimed seeds. In the summer-planted field experiments and in the laboratory tests at $15 \mathrm{C}$, seedlings from primed seed emerged an average of 1 day $(10 \%)$ sooner than those from unprimed seed.

While seed priming resulted in faster emergence, priming resulted in increased maximum emergence in only one of the four field experiments and in none of the laboratory experiments. Maximum emergence was uniformly high in the laboratory emergence experiments at $15 \mathrm{C}$, averaging $92 \%$. The potting mix used in the laboratory experiments will not crust and no diseases were evident. Thus, maximum emergence in the laboratory experiments represent the emergence potential of these seed lots under optimal conditions. Priming would only be expected to improve maximum emergence under optimal conditions if the priming treatment reversed previously sustained injury (Burgass and Powell, 1984). While priming has been shown to improve maximum emergence in some poorly emerging seed lots of carrot (Daucus carota L.) and celery [Apium graveolens (L.) var. dulce Mill.] (Brocklehurst and Dearman, 1983b), this was not true for onions in either our study or those of Dearman et al. (1986).

In 1986, all cultivars emerged in the field at similar rates. The range of $\mathrm{T}_{50}$ values among cultivar means varied from 1.3 days in the spring field experiment to 0.5 days in the summer laboratory experiment (Table 2). Significant cultivar differences were detected in only one laboratory experiment. In contrast, significant cultivar differences in $\mathrm{T}_{50}$ were measured in all experiments using the 1987 seed lots. 'Bronze Wonder' generally emerged slower and 'Challenger' faster than the other cultivars. However, cultivar ranks were not consistent across all experiments in 1987. Laboratory $\mathrm{T}_{50}$ values were significantly correlated with $\mathrm{T}_{50}$ in the field in three of the four field plantings, although correlation coefficients were low $(r=0.38$ to $r=0.45)$.

Cultivar differences in maximum field emergence were observed in only one of the four field experiments. Maximum field emergence was generally lower in the summer experiments than in the spring, averaging $60 \%$ and $71 \%$, respectively. This result is in agreement with Hegarty's (1976) observation that final emergence of onion seedlings decreased as soil temperatures at planting increased. Significant cultivar differences in maximum emergence were observed in the 1987 laboratory experiments, but not in 1986 (data not shown). No correlation was found between maximum emergence in the laboratory and maximum emergence in the field.

Priming reduced time to emergence by an average of $10 \%$ across all experiments, but improved final emergence in only one springplanted experiment. Spring field plantings benefited more from priming than summer plantings. Laboratory emergence was weakly correlated with field emergence. Cultivar response varied with seed lots and with environments. This variability continues to be an obstacle to the prediction of cultivar responses as well as evaluation and application of priming technology (Heydecker, 1977).

\section{Literature Cited}

Brocklehurst, P.A. and J. Dearman. 1983a. Interactions between seed priming treatments and nine seed lots of carrot, celery, and onion. I. Laboratory germination. Ann. Applied Biol. 102:577-584

Brocklehurst, P.A. and J. Dearman. 1983b. Interactions between seed priming treatments and nine seed lots of carrot, celery, and onion. II. Seedling emergence and plant growth. Ann. Applied Biol. 102:585-593.

Burgass, R.W. and A.A. Powell. 1984. Evidence for repair processes in the invigoration of seeds by hydration. Ann. Bot 53:753-757.

Dearman, J., P.A. Brocklehurst, and R.L.K. Drew. 1986. Effects of osmotic priming and aging on onion seed germination. Ann. Applied Biol. 108:639-648

Furutani, S.C., B.H. Zandstra, and H.C. Price. 1986. The effects of osmotic solute composition and duration and temperature of priming on onion seed germination. Seed Sci. \& Technol. 14:545-551.

Hegarty, T.W. 1976. Field establishment of some vegetable crops: Response to a range of soil conditions. J. Hort. Sci. 51:133-146.

Heydecker, W. 1977. Stress and seed germination, p. 240-282. In: A.A. Kahn (ed.). The physiology and biochemistry of seed dormancy and germination. Elsevier, Northern Holland, Amsterdam.

Lipe, W.N. and J.A. Skinner. 1979. Effect of sowing pregerminated onion seeds in cold soil on time of emergence, maturity, and yield. HortScience 14:238-239.

Shock, C., T. Steiber, C. Stanger, and J. Ishida. 1989. Onion plant density, row spacing, and maturity group effects on bulb yield and market grade. Proc. Natl. Onion Res. Conf. p. 19-31.

Young, D.H. 1989. A cultural and plant population study to optimize marketable pack out of eastern U.S. pre pack onions. Proc. Natl. Onion Res. Conf. p. 47-52. 